\title{
THE INFLUENCE OF METEOROLOGICAL FACTORS ON ROCKFALL IN THE MORAVSKOSLEZSKÉ BESKYDY MTS.
}

\begin{abstract}
BRÁZDIL, R., ŠILHÁN, K., PÁNEK, T., DOBROVOLNÝ, P., KAŠIČKOVÁ, L., TOLASZ, R. (2012): The influence of meteorological factors on rockfall in the Moravskoslezské Beskydy Mts. Geografie, 117, No. 1, pp. 1-20. - Rockfall rate (RR) series for four sites in the Moravskoslezské Beskydy Mountains (Smrk1, Smrk2, Ropice and Satina) were created for the period 1931-2008, using a dendrogeomorphic approach. Meteorological stations from the immediate area were also selected to study the influence of meteorological factors on rockfall. Monthly, seasonal, and annual mean air temperatures (TM), number of days with transitions of temperatures through $0{ }^{\circ} \mathrm{C}(\mathrm{Tr} 0)$ and precipitation totals $(\operatorname{Pr})$ were used for this analysis. Despite the complexity of the rockfall process, uncertainty in the development of RR series and uncertainty in local meteorological patterns, there exist statistically significant correlation coefficients between $\mathrm{RR}$ series and meteorological variables. Multiple stepwise linear regression allows explanation of up to $43 \%$ (Satina in 1975-2008) of the RR variability by meteorological factors. Tr0, followed by TM, are the most important factors, while the influence of $\operatorname{Pr}$ was demonstrated only randomly.
\end{abstract}

KEY WORDS: rockfall - dendrogeomorphology - regelation cycle - meteorological factors air temperature - precipitation - Moravskoslezské Beskydy Mts.

This paper was prepared with financial support from the Grant Agency of the Czech Republic, grant ref. No. P209/10/0309 "The effect of historical climatic and hydrometeorological extremes on slope and fluvial processes in the Western Beskydy Mts. and their forefield".

\section{Introduction}

Rockfall is a dangerous geomorphic process, regularly leading to damage to property, with all the significant financial losses, and even human fatalities, that this involves. For example, after a severe succession of rockfalls and other slope processes following extreme precipitation totals in Czechia in July 1997, more than 100 million Czech crowns had to be invested in the stabilization of the slopes involved (Falc 2001). In the Hrrensko area, which is the part of Czechia most threatened by rockfall, more than 13 million Czech crowns was allocated for stabilization of rocks during the years 2008-2010 (http://www. ceskesvycarsko.cz/news-dtl.php?id=1166).

Knowledge of rockfall triggering factors is vital to prediction of its potential occurrence, and thus to any preventive action. Obtaining long-term records of rockfall activity can contribute very constructively to finding out exactly what these factors are. Long-term field monitoring is usually needed for quantification of rockfall intensity (Zvelebil, Moser 2001; Matsuoka 2008). For example, 
rockfall has been monitored continuously for the sandstones of NW Bohemia since 1979 (Zvelebil 1995). In such a context, dendrogeomorphic techniques enable reconstruction and quantification of rockfall dynamics over longer time scales, looking back as far as several centuries (Stoffel et al. 2005).

Meteorological conditions are considered among the triggering factors in the creation of rockfall. Air temperatures and precipitation play major roles, but windstorms also have a part (Rapp 1960). However, the rockfall process is highly complex and many other factors may be decisive, among them earthquakes (Marzorati, Luzi, de Amicis 2002; Becker, Davenport 2005; Coe, Harp 2007) and weathering processes (Jaboyedoff et al. 2004). It is therefore difficult to demonstrate relations and express them in quantitative form.

The impacts of meteorological factors on rockfall have been analyzed, for example, by Sandersen et al. (1997), Matsuoka, Sakai (1999), Gruner (2008) and Schneuwly, Stoffel (2008b). Various parameters emerge as worthy of mention as possible causes for rockfall. Davies, Hamza, Harris (2001) investigated overall increase in rockfall activity associated with rises in mean annual temperature. For more detailed time-scales, Perret, Stoffel, Kienholz (2006), working in the Swiss Alps, observed correlations between mean summer and winter temperatures and the frequency of rockfall. Other studies addressing the relationships between various hydrometeorological phenomena and the occurrence of rockfall in high-mountain areas have pointed out the significant influence of heavy rainstorms, exceeding $90 \mathrm{~mm} / 24 \mathrm{~h}$ (Schneuwly, Stoffel 2008b), and the effect of the melting permafrost (Gruber, Hoelzle, Haeberli 2004; Ravanel, Deline 2011). Rybár $(1999,2007)$ mentions that the spreading of rock slopes, together with minor rockfalls, are affected by daily temperature variations. Regelation (freeze-thaw) cycles have been studied e.g. by Matsuoka (2008). According to Matsuoka, Sakai (1999), a maximum rockfall rate is achieved between 5 and 15 days after snow-melt.

At the sites analyzed in the Moravskoslezské Beskydy Mountains, rockfall poses a very real hazard to forest roads situated downslope. Worse, however, is the situation in other areas in Czechia (especially the sandstone landscapes of northern Bohemia, around Hřensko, etc.), where rockfall is considered a major hazard and gives rise to significant damage to infrastructure and even endangers human lives (Zvelebil 1995; Stemberk, Zvelebil 1998; Zavoral 2002; Vařilová, Zvelebil, Paluš 2011). Kukal and Pošmourný (2005) estimated the recurrence of catastrophic rockfall $\left(>10^{3} \mathrm{~m}^{3}\right)$ in northern Bohemia to be once every 9-11 years. Minor rockfall $\left(<10^{3} \mathrm{~m}^{3}\right)$ occurs in this region every $5-6$ years. In contrast, the area of the Flysch Carpathians is characterized by significantly lower frequency and magnitude of rockfall activity (see also Brázdil, Kirchner, eds. 2007). The largest recently-documented events in the latter part of Czechia were triggered by heavy and persistent rainfall in July 1997 (Kirchner, Krejčí 1998; Kirchner et al. 2000) and during April 2001. The volume of fallen blocks of rock did not exceed $100 \mathrm{~m}^{3}$ in the Czech part of the Western Carpathians (Krejčí et al. 2002; Klimeš 2011).

This paper focuses on the relationships between meteorological factors and rockfall data as derived through a dendrogeomorphic approach to four sites in the Moravskoslezské Beskydy Mountains. It significantly extends the results of meteorological analyses partly presented by Šilhán et al. (2011). After defining the type of area studied (section 2), the rockfall and meteorological data are 
described in section three. Section four outlines our methods of analysis and section five shows fluctuations in the rockfall series and their relationships to temperature and precipitation. Section six discusses the results obtained and the final section offers some concluding remarks.

\section{Area studied}

The Moravskoslezské Beskydy Mountains are a part of the thrust-and-fold belt of the Flysch Carpathians, which were formed during the Miocene (Menčík et al. 1983; Fig. 1). The main landforms are derived from the monoclinal structure of the Cretaceous-Oligocene flysch bedrock (sandstones alternating with claystones and mudstones), dipping slightly $\left(5-20^{\circ}\right)$ towards the south and south-east (Menčík et al. 1983). The culmination parts of the mountains (Lysá hora Mt., 1,323 $\mathrm{m}$ ) have the highest annual precipitation total in the Czech Republic (1,407 mm per year in the 1961-2000 period) with maxima in summer (208 mm in July). Mean annual temperature is $2.6{ }^{\circ} \mathrm{C}$ (Tolasz et al. 2007). Relatively steep slopes, low rock strength and high precipitation totals make the area prone to various types of slope deformations (Hradecký, Pánek 2008). Rockfall is mostly related to undercut banks, structural escarpments and steepened zones (headscarps or frontal blocks) of bedrock landslides.

Four forested scree slopes (Smrk1, 49 $29.1^{\prime} \mathrm{N} / 18^{\circ} 20.8^{\prime} \mathrm{E}$; Smrk2, 49²8.9' N / 18 $21.1^{\prime}$ E; Ropice, $49^{\circ} 35.9^{\prime} \mathrm{N} / 18^{\circ} 35.0^{\prime} \mathrm{E}$; and Satina, $49^{\circ} 33.5^{\prime} \mathrm{N} / 18^{\circ} 26.2^{\prime} \mathrm{E}$;

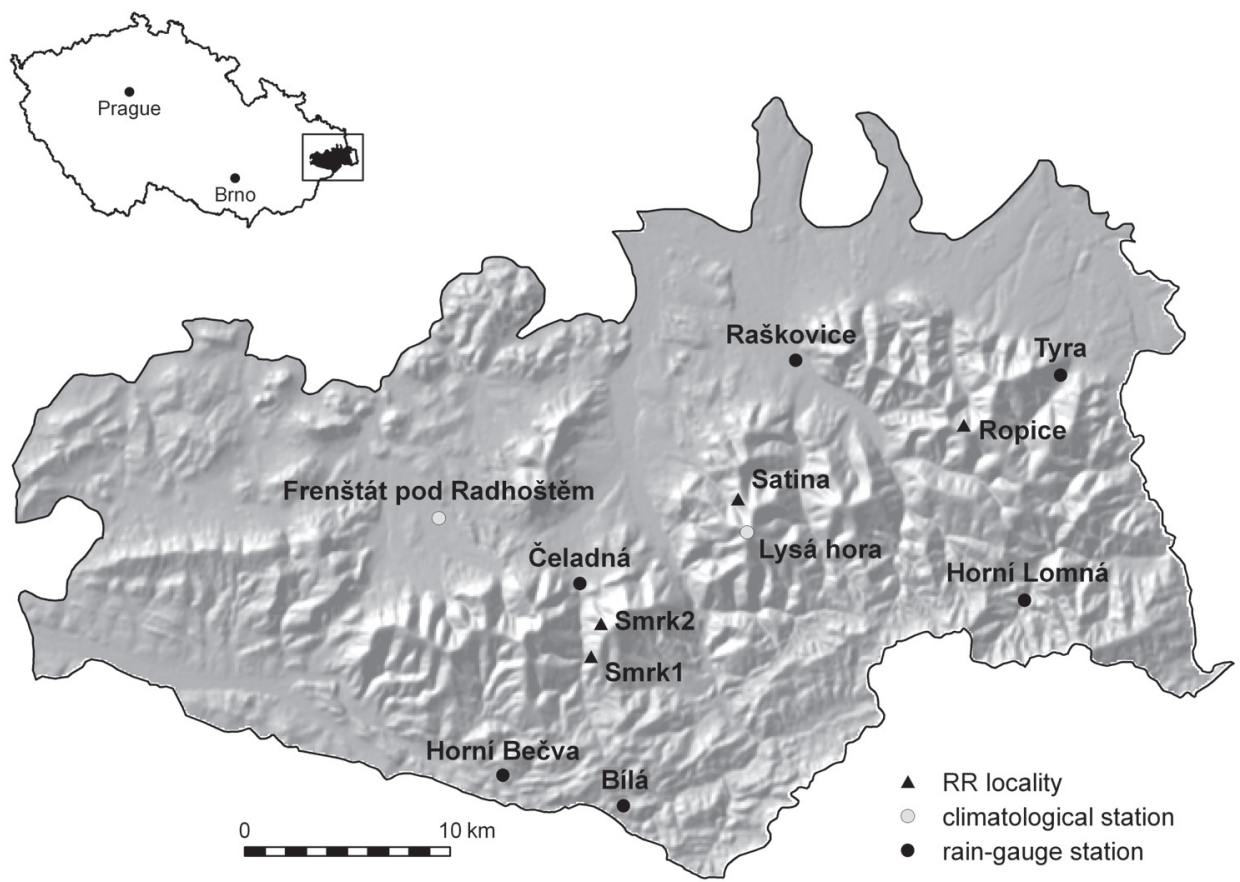

Fig. 1 - The area studied, with the positions of the rockfall sites and meteorological stations involved 
Table 1 - Basic characteristics of the localities studied

\begin{tabular}{|c|c|c|c|c|c|}
\hline \multirow[t]{2}{*}{ Locality } & \multirow{2}{*}{$\begin{array}{l}\text { Upper edge of rock wall - } \\
\text { scree slope termination } \\
\text { (altitude, m) }\end{array}$} & & & & \\
\hline & & Orientation & $\begin{array}{l}\text { Length } \\
\text { (m) }\end{array}$ & $\begin{array}{l}\text { Height } \\
\text { (m) }\end{array}$ & $\begin{array}{l}\text { Inclination } \\
\left(^{\circ}\right)\end{array}$ \\
\hline Smrk1 & $600-650$ & $\mathrm{~W}$ & 40 & 7 & $50-90$ \\
\hline Smrk2 & $810-870$ & NW & 40 & 10 & 70 \\
\hline Ropice & $910-970$ & $\mathrm{~N}$ & 80 & 30 & $50-90$ \\
\hline Satina & $800-870$ & $\mathrm{~W}$ & 120 & 40 & $50-90$ \\
\hline
\end{tabular}

Fig. 1) were selected for dendrogeomorphic research. Nearly all of the trees in each locality display evidence of active rockfall in the form of various types of disturbance (scars, tilting, broken branches, decapitation, etc.). All the rockfall slopes studied, and especially their cliffs, are underlined by tectonically disturbed, gravitationally relaxed, thick-bedded sandstones of the Middle Godula Member (Cretaceous). The slopes are covered with forest particularly dominated by sycamore maple (Acer pseudoplatanus L.), Norway spruce (Picea abies L.) Karst.), European beech (Fagus sylvatica L.), mountain ash (Sorbus aucuparia L.) and wych elm (Ulmus glabra Huds.).

Smrk1 is situated at the foot of the western slope of Mount Smrk (1,276 m) on what was once an undercut bank of the River Čeladenka. Smrk2 lies at a

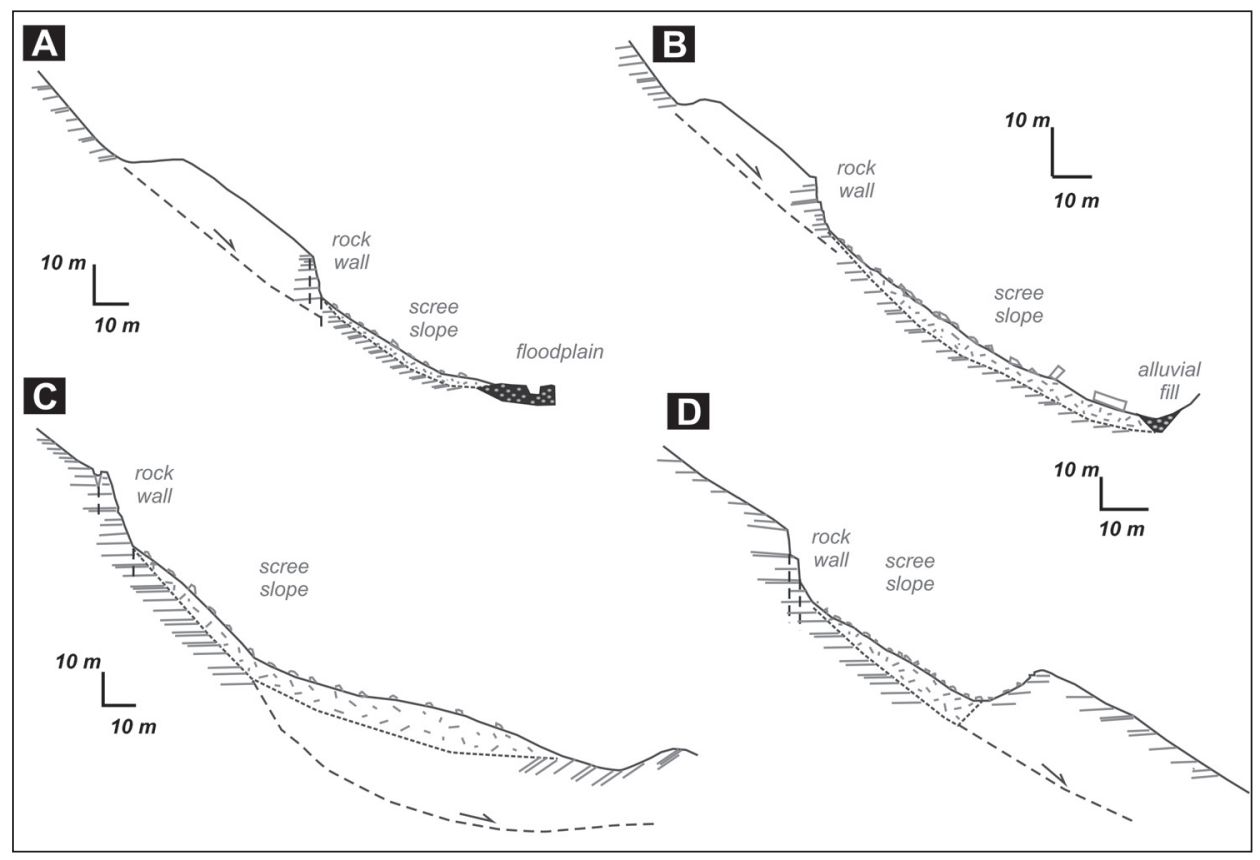

Fig. 2 - Topographic profiles of the rockfall sites studied: A - Smrk1, B - Smrk2, C - Ropice, D - Satina 


\begin{tabular}{|llll|}
\hline Rock wall & & & $\begin{array}{l}\text { Length } \\
\text { of scree } \\
\text { slope }(\mathrm{m})\end{array}$ \\
\hline Geomorphic context & $\begin{array}{l}\text { Joint spacing } \\
(\mathrm{m})\end{array}$ & $\begin{array}{l}\text { Occurrence } \\
\text { of faults }\end{array}$ & yes \\
\hline $\begin{array}{l}\text { front of bedrock landslide incised by valley } \\
\text { lateral erosion }\end{array}$ & $0.4-0.6$ & no & $15-60$ \\
\hline landslide scarp & $0.8-1.0$ & yes & 70 \\
\hline landslide scarp & $0.3-1.0$ & yes & 40 \\
\hline
\end{tabular}

higher altitude within the western slope of Mount Smrk. The Ropice locality is situated on the northern slope of Mount Ropice $(1,083 \mathrm{~m})$ and is strongly gravitationally disrupted (Pánek et al. 2009). The rockfall source area is the amphitheatre-shaped headscarp of a huge rotational landslide that originated $>1.5$ ka BP (Pánek et al. 2009). In morphological contrast to other rock faces that have been studied, this rockfall source area does not consist entirely of a rock cliff. Some portions of the headscarp are significantly weathered but stabilized by vegetation. The Satina rockfall slope occupies the right valley slope of the River Satina in the north-western part of Lysá hora Mt. (1,323 m). The morphometric and morphologic properties of all the localities studied are presented in Table 1. Figure 2 shows slope profiles of the four sites involved in the study.

\section{Data}

\subsection{Rockfall data}

The historical intensity of rockfall for the purposes of this study was obtained using dendrogeomorphic methods. The term "rockfall" is used to describe the free or rebounding fall of individual or a limited number of superficial rockfall fragments from rock faces down steep slopes, with volumes involved generally $<5 \mathrm{~m}^{3}$ (Berger, Quetel, Dorren 2002). Rockfall acting on the sites studied does not usually exceed this value. The field approach was based on taking four increment cores (one upslope, one downslope and two perpendicular to slope at height of maximum density of visible scars) from each tree living below rockfaces obviously disturbed by rockfall (scars, tilting of trunk, broken branches, decapitation). Based on detailed investigation of wider areas of rockfall sites, we may exclude the possibility that tree-ring disturbances were caused by other (non-rockfall) geomorphic processes (e.g. debris flows or snow avalanches). Samples were analyzed by standard dendrochronological procedures as described e.g. by Bräker (2002). Single steps included drying the samples, sticking them to supports, sanding, counting of tree-rings and measuring the widths of rings (to within $0.01 \mathrm{~mm}$ ) using TimeTable and PAST4 software. Thirty undisturbed trees of each species were also sampled for reference in chronology reconstruction. Reference chronologies were established for "normal" growth conditions 
(influenced by only climate variations and occasional insect outbreaks) at the given locations. Comparison of samples from disturbed trees with the reference chronology enabled identification and correction of false/missing rings and decoupling of climatic influences from the impacts of rock fragments on identified growth disturbances. Individual rockfall events were identified and dated by visual inspection of sample surfaces and from increment curves. Growth disturbances associated with rockfall impacts largely comprise abrupt growth suppression (reaction of tree to stem damage or decapitation), abrupt growth release (reaction of a tree to reduction of competition due to the death of neighbouring trees through rockfall impact), reaction wood (reaction of tree to changes in its inclination), callous tissue (specific chaotic tissue overgrowth at the edges of injuries) and tangential rows of traumatic resin ducts (TRD), a reaction on the part of some coniferous species to stem damage (Schneuwly, Stoffel 2008a).

Intensity of rockfall was expressed as "rockfall rate" (RR) (Stoffel et al. 2005; Perret, Stoffel, Kienholz 2006):

$R R=\sum R E y \div E D y$,

where $R E$ is rockfall events dated to year $y$, and $E D$ is the sum of the diameters of all trees in year $y$. The $E D$ of one tree in year $y$ is defined as the annual increment rate of the tree multiplied by the age of the tree in years. Annual increment rate was calculated as tree diameter (calculated from the tree circumference measured at sampling height) divided by tree age. For the purposes of this study, $R R$ values are considered relevant only if calculated from ED > 30\% of ED in 2008 (1975-2008 for Smrk1, 1931-2008 for Smrk2 and Ropice, 1937-2008 for Satina).

A total of 1,132 increment cores from 283 trees growing in the rockfall transport and accumulation zones enabled the dating of 989 rockfall events.

\subsection{Meteorological data}

The meteorological data used in the study of their relationships with $R R$ is significantly hampered by:

(i) the resolution of the $\mathrm{RR}$ series can be no better than annual (i.e. time resolution cannot be specify for any particular part of the year)

(ii) the position of the sites studied

(iii) the great complexity of relations between $R R$ and other local or regional triggering factors.

It follows that meteorological factors can explain only a certain portion of $R R$ variability.

These difficulties may be addressed, if not overcome, by applying the following approaches:

(i) without exact knowledge of a corresponding rockfall date in individual years, it is impossible to base any analysis on daily data that has to be averaged for any longer period, such as a month, a season or a year, which means that long series of RR can be compared only with monthly, seasonal and annual meteorological series

(ii) no meteorological stations with long-term observations are located exactly at the positions of the sites studied, i.e. we have to use whatever meteorological 
stations are available in the standard network of the Czech Hydrometeorological Institute (CHMI)

(iii) air temperature and precipitation appear to be the most important meteorological elements influencing RR (e.g. Luckman 1976; Ishikawa, Kurashige, Hirakawa 2004).

Taking the above facts into consideration, it proved possible to use series of temperature and precipitation from several CHMI meteorological stations located in the area studied. For temperatures, the four sites analyzed may be characterized by the Frenštát pod Radhoštěm (Fr) station, representing a basin position (altitude $436 \mathrm{~m}$ ) and the Lysá hora $(\mathrm{LH})$ station for the top position $(1,322 \mathrm{~m})$. All the study sites lie at altitudes between $\mathrm{Fr}$ and LH, i.e. it appears reasonable to use the two stations for analysis. A further supporting factor is the very high correlation between the Fr and LH stations. The distances separating the two meteorological stations from the study sites (the smallest between LH and Satina at $1.7 \mathrm{~km}$ and the largest between Fr and Ropice at $26.2 \mathrm{~km}$ ) are fully comparable with similar studies (Perret, Stoffel, Kienholz 2006; Schneuwly, Stoffel 2008a, 2008b). For precipitation, characterized by greater spatial variability, a further six rain-gauge stations were added to Lysá hora: Bílá (altitude 770 m), Čeladná (510 m), Horní Bečva (565 m), Horní Lomná (594 m), Raškovice (397 m), and Tyra (500 m). The distances that separate them from the $R R$ sites analysed are within the limits mentioned above.

\section{Methods of analysis}

The CHMI meteorological stations that span the whole period of the RR series (1931-2008) have some missing data, or some of the station records started as late as the 1950s. It was therefore necessary to fill in missing data and, because of possible changes in station positions as well as in measurements proper, homogenise them using the Standard Normal Homogeneity Test (SNHT) by Alexandersson $(1986,1995)$ with AnClim software (Štěpánek 2007).

The air temperature data used are represented by monthly mean temperatures (TM) and number of days with transitions of temperatures through $0^{\circ} \mathrm{C}$ (Tr0). Firstly, the TM series of the Fr station were homogenised with respect to the Rožnov pod Radhoštěm station (measurements from 1924-1971) with completion of missing or unreliable data. The corrected Fr series was then compared with the homogeneous Czech Republic series (Štěpánek 2004) and adjusted. Similarly, the LH station was compared with Czechia series, completed for missing data and adjusted. In such a way complete and homogeneous TM series of Fr and LH for the 1931-2008 period were obtained.

Days with transitions of temperatures through $0^{\circ} \mathrm{C}(\operatorname{Tr} 0)$ in this context are understood as days in which daily maximum temperature $\mathrm{TMAX}>0^{\circ} \mathrm{C}$ and daily minimum temperature $\mathrm{TMIN}<0^{\circ} \mathrm{C}$. Missing temperature extremes for Frenštát pod Radhoštěm, from which Tr0 was calculated, were completed, once more with reference to the Rožnov pod Radhoštěm station for January-April and October-December in 1955-1971. The missing data in the 1934-1971 period for the LH station were completed in a similar way.

SNHT for monthly precipitation series $(\mathrm{Pr})$ showed some inhomogeneities in selected months, but without any relation to metadata or to "indubitable" 
inhomogeneities (Brázdil, Štěpánek 1998). The series was therefore not justified. After this procedure, missing data were completed based on the highest correlation coefficients between stations: for Lysá hora according to Čeladná, for Horní Bečva according to Bílá and vice versa, and finally for Tyra according to Raškovice.

Pearson correlation coefficients between RR series and corresponding meteorological parameters TM, Tr0 and Pr were calculated for monthly, seasonal and annual values (Figs. 4-6) as well as for other combinations of months. The statistical significance of the results was evaluated with the one-tailed t-test at a significance level of $\alpha=0.05$. As the distribution of $R R$ values deviates from the normal (Gaussian) distribution for the above-mentioned characteristics, the Spearman rank correlation coefficient was also calculated but its values did not differ significantly from the previous Pearson correlations.

The meteorological parameters with the highest correlation coefficients to $\mathrm{RR}$ series were further selected for multiple stepwise linear regression analysis to demonstrate the importance of the three parameters studied for the highest proportion of explained variance in RR series. We utilized a forward stepwise model of multiple regression that evaluates the independent variables at each step, adding or deleting them from the model on the basis of initial user-specified criteria. Characteristics with the highest values of statistically significant correlations were always selected for evaluation of the regression model.

\section{Results: relationships between meteorological factors and rockfall}

\subsection{Rockfall rate}

Fluctuations in the four resulting $R R$ series are shown in Figure 3. The complexity of the rockfall process is already reflected in correlations between these series. In 1975-2008, significant correlations emerged between RR at Ropice and Smrk1, Smrk2 and Satina (0.40, 0.63 and 0.35) and Smrk2 with Satina (0.36). On the other hand, the closest sites, Smrk1 and Smrk2, have only a low and insignificant correlation coefficient (0.15). Extension of the study period results in a decrease in relationships; for 1937-2008, a statistically significant correlation coefficient exists for Smrk2 with Ropice (0.24) and Satina (0.47).

\subsection{Air temperature}

Monthly, seasonal and annual mean temperatures (TM) show generally negative correlations with RR series (Fig. 4), i.e. higher values of $R R$ correspond to lower temperatures. Insignificant correlations largely prevail. Despite close agreement, in some cases they also differ from site to site as well as from period to period, something that may indicate a higher degree of complexity among existing relations. This may be demonstrated for the 1975-2008 period. For example, well-expressed negative correlations occur in April, significant for Smrk2 and Satina. But significant December correlations for Smrk1 are absent for Smrk2, a closed site. Temporal changes in significant correlations may be 
documented for Smrk2: in the 1975-2008 period these occur in April and July, in 1937-2008 February, May, July, winter (DJF), summer (JJA) and annually, and finally in 1931-2008 May, July and autumn (SON). The differences in correlations with respect to the station used (i.e. Fr or LH) are unimportant. Of all the four sites, only Satina shows significant positive correlations (February in 1975-2008 and September in 1937-2008).

\subsection{Days with transitions through $0{ }^{\circ} \mathrm{C}$}

Monthly, seasonal and annual numbers of days with transitions through $0^{\circ} \mathrm{C}$ show prevailingly positive correlations with $\mathrm{RR}$ series (Fig. 5), i.e. more
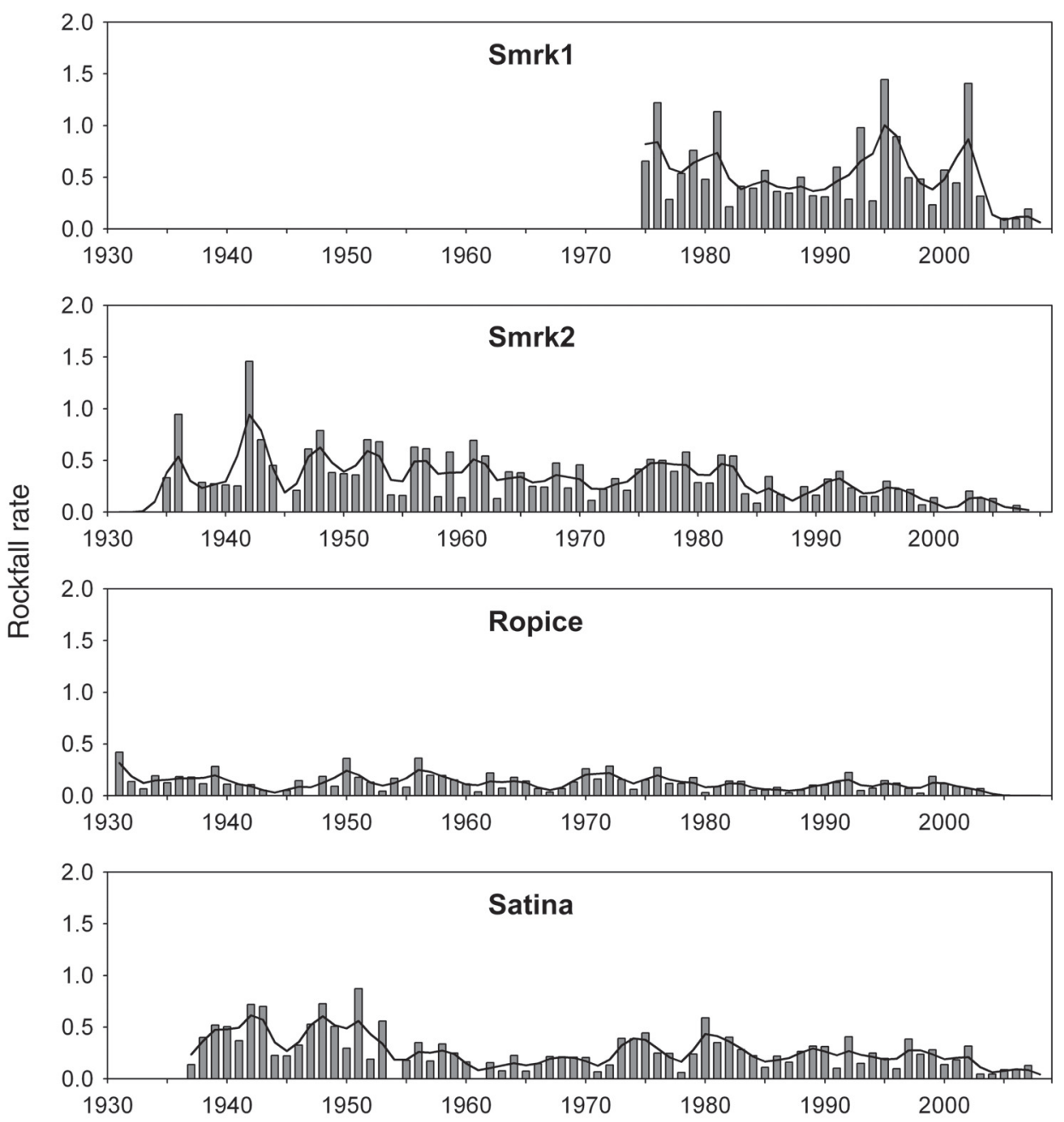

Fig. 3 - Fluctuations in annual RR series at four sites studied, smoothed by 5-year Gaussian filter over the 1931-2008 period 

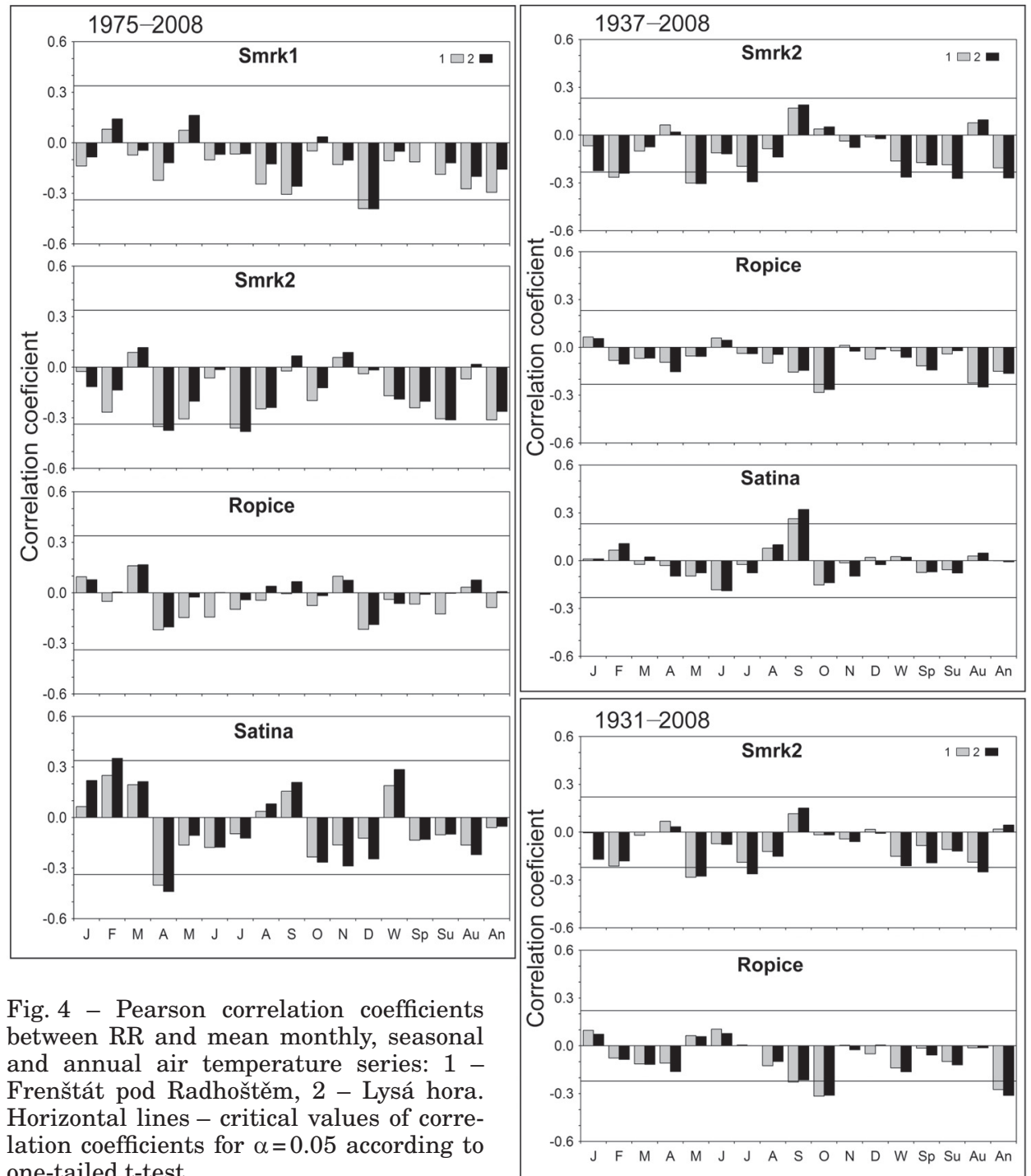

Fig. 4 - Pearson correlation coefficients between RR and mean monthly, seasonal and annual air temperature series: 1 Frenštát pod Radhoštěm, 2 - Lysá hora. Horizontal lines - critical values of correlation coefficients for $\alpha=0.05$ according to one-tailed t-test.

frequent transitions through $0^{\circ} \mathrm{C}$ support higher $\mathrm{RR}$ values. Significant positive correlations are typical of winter, January and February in the 1975-2008 period, even for absolutely the highest calculated correlation coefficients (Smrk2 and Ropice). Because of higher variability in winter temperatures at lower positions compared to mountain-tops, correlations with the Fr station are generally better than for LH. Temporal extension of the RR series again alters which correlation coefficients are significant. For example, in the 1937-2008 period, new significant positive correlations appear in May-June, December and in annual values for Smrk2, in October for Ropice and in March for Satina. 
Monthly, seasonal and annual precipitation totals $(\mathrm{Pr})$ correlate with RR series more randomly than TM and Tr0 (Fig. 6). They can be in total contrast even at sites that lie close to one another (such as Smrk1 and Smrk2). Significant correlation coefficients occur very rarely, only June at Satina in 1975-2008, January, August and annual values for Smrk2 in 1937-2008 and for Smrk2, September, winter and summer in 1931-2008 as well. Because of the great variability in spatial precipitation, the mean precipitation series from stations in the surroundings of the sites studied (e.g. for Celadná, Lysá hora, Bílá and Horní Bečva for Smrk1 and Smrk2) were calculated (not shown) but correlations did not improve when compared to the actual stations shown in Figure 6.
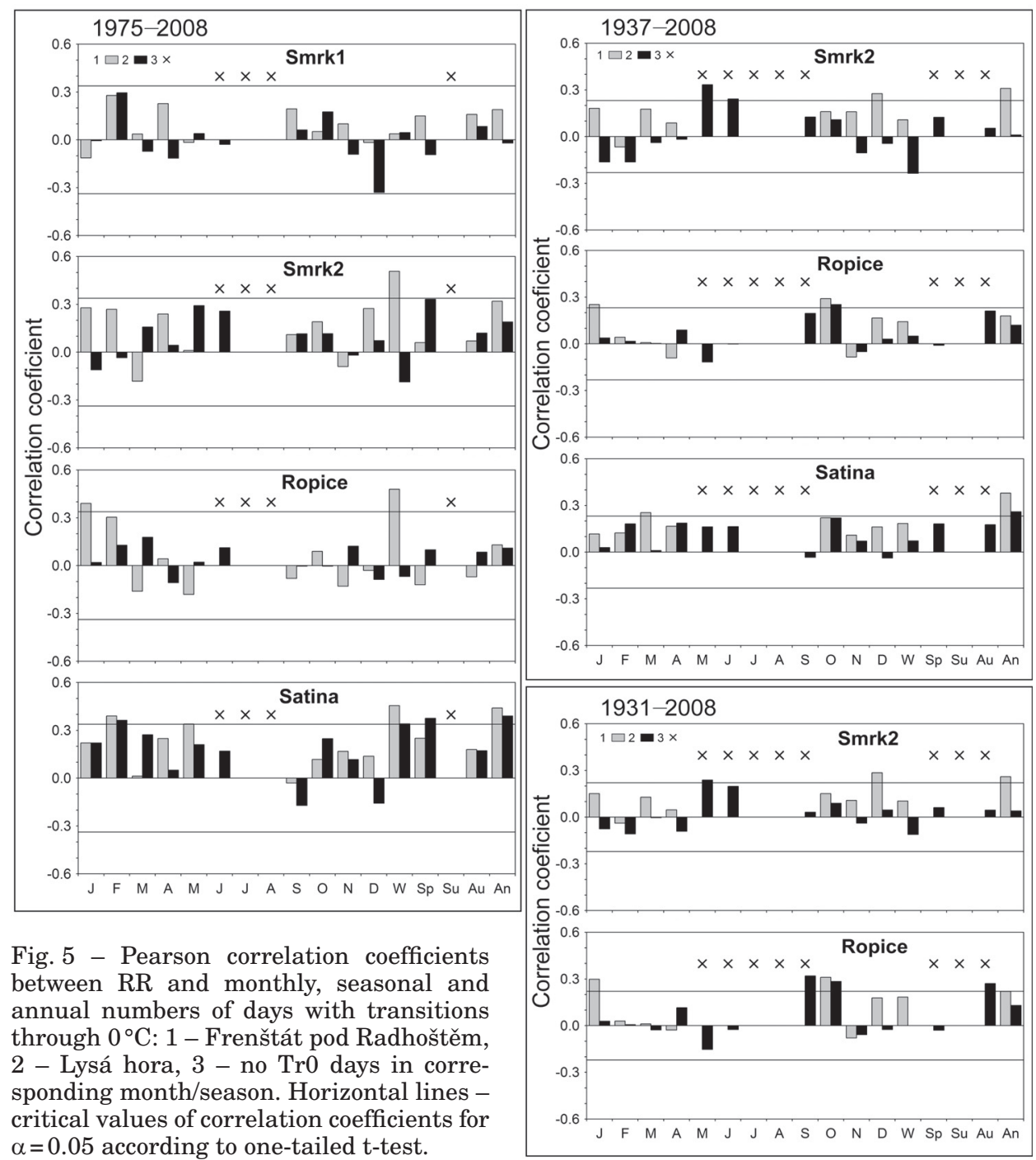

Fig. 5 - Pearson correlation coefficients between RR and monthly, seasonal and annual numbers of days with transitions through $0^{\circ} \mathrm{C}: 1-$ Frenštát pod Radhoštěm, 2 - Lysá hora, 3 - no Tr0 days in corresponding month/season. Horizontal lines critical values of correlation coefficients for $\alpha=0.05$ according to one-tailed t-test. 


\subsection{Combined effect of meteorological variables}

The method of multiple stepwise linear regression was applied to show how including more meteorological parameters increases the share of the explained variance in fluctuations in $R R$ series.

Figure 7 demonstrates the method employed, using the example of Satina for the 1975-2008 period. Three selected predictands (factors) explain individually

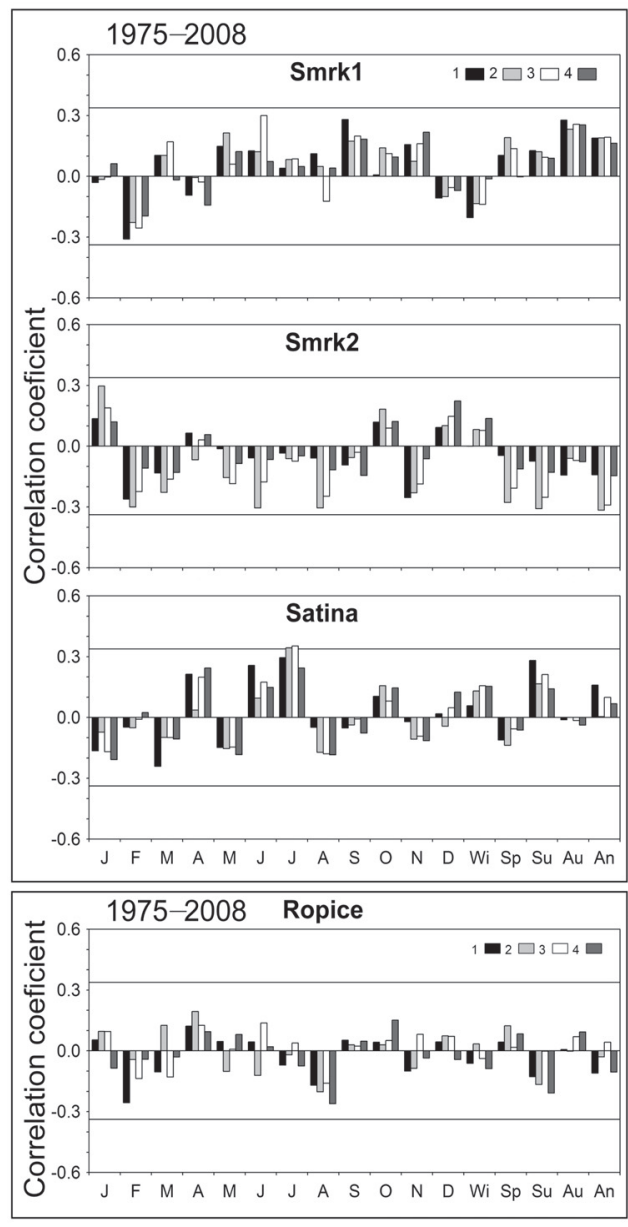

Fig. 6 - Pearson correlation coefficients between RR and monthly, seasonal and annual series of precipitation totals: 1 Lysá hora, 2 - Bílá, 3 - Horní Bečva, 4 Čeladná; Ropice 1975-2008: 1 - Lysá hora, 2 - Horní Lomná, 3 - Raškovice, 4 - Tyra. Horizontal lines - critical values of correlation coefficients for $\alpha=0.05$ according to one-tailed t-test.

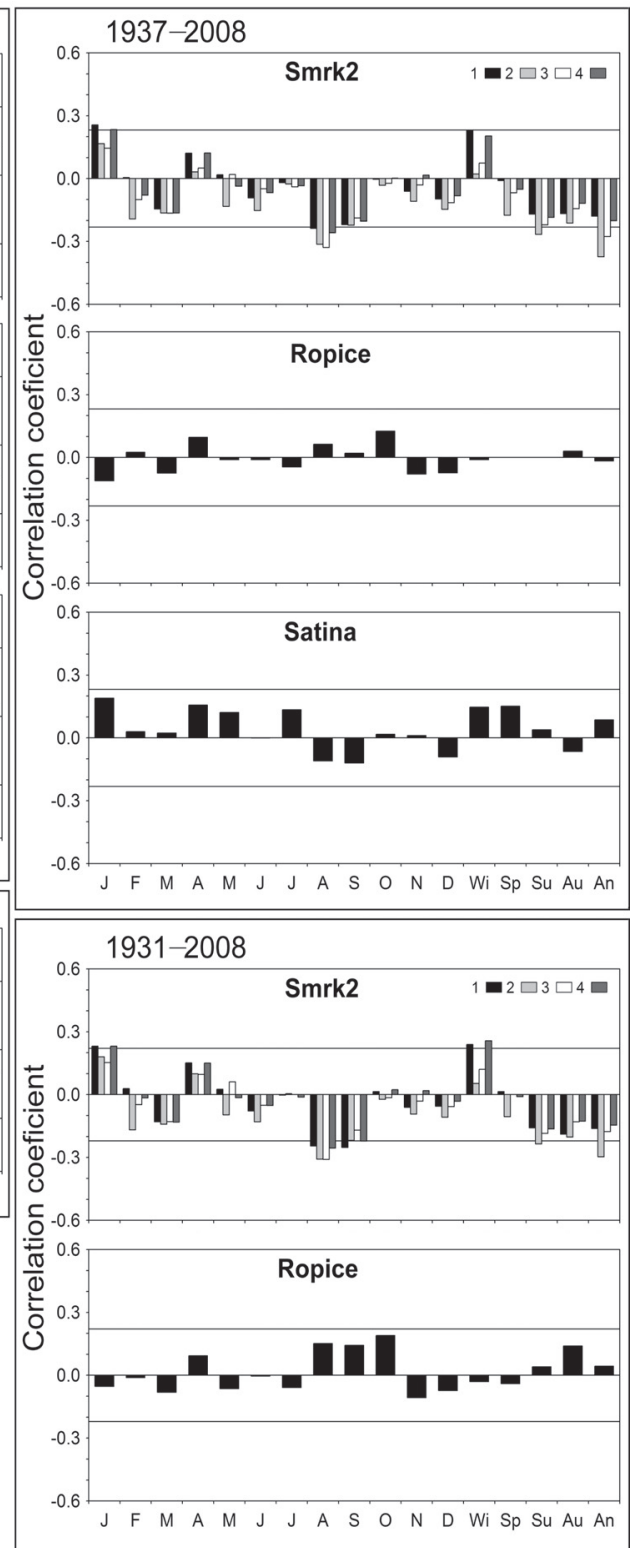




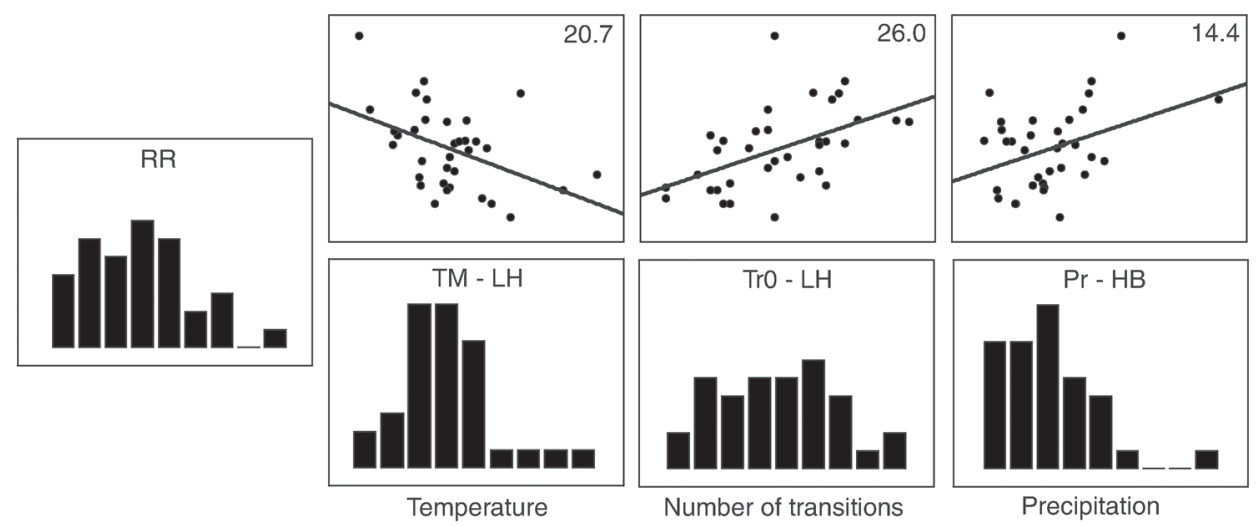

Fig. 7 - Histograms of predictor (RR) and predictand (TM-LH, Tr0-LH, Pr-HB) values and scatter plots between them with fitted simple linear regression for Satina, 1975-2008. Numbers indicate the variance in the $R R$ series explained by individual predictands (in \%).

between 26.0\% (Tr0-LH) and $14.4 \%$ (Pr-HB) of the variability of the RR (predictor) series. Applying the final multiple regression model

$$
R R=-0.1105+0.0053 \operatorname{Tr} 0-L H-0.0392 T M-L H+0.0004 P r-H B,
$$

the explained variance of $R R$ increases to $43.0 \%$ (37.2\% is the adjusted explained variance that takes into consideration the number of predictors). The contribution of predictands Tr0-LH and TM-LH to the overall explained variance is statistically significant while this is not a case for the Pr-HB predictand.

In terms of locality and period analysed, nine such regression models were compiled (Table 2). The first predictand (factor) entering the regression model was statistically significant for all nine tested cases. The analysis confirmed the importance of temperature characteristics TM and Tr0. While Tr0 entered the regression model as the first (thus, the most correlated) factor in five cases, TM took priority in three cases. Thus Tr0 appears to be generally more important in explaining RR variability than TM. However, their combined effect for explained $R R$ variance was found to be statistically significant only for Satina in the periods 1975-2008 and 1937-2008 with the highest explained variance (43.0 and $23.7 \%$, respectively) compared to other sites. The influence of precipitation totals on RR variability is generally weaker, significant only for Smrk2 in 1931-2008 (with the Bílá station) supplying, together with TM and Tr0, some $24.6 \%$ of explained variance. Even if the role of precipitation totals is minor, the final model explains a reasonable number of $R R$ values. The lowest explained variance, at 12.9\%, was calculated for Ropice in the 1937-2008 period.

\section{Discussion}

The time-series of RR obtained correlate quite well with one another, which suggests the existence of general conditions driving rockfall activity in the region. Since this area is more-or-less aseismic (the most disastrous known 


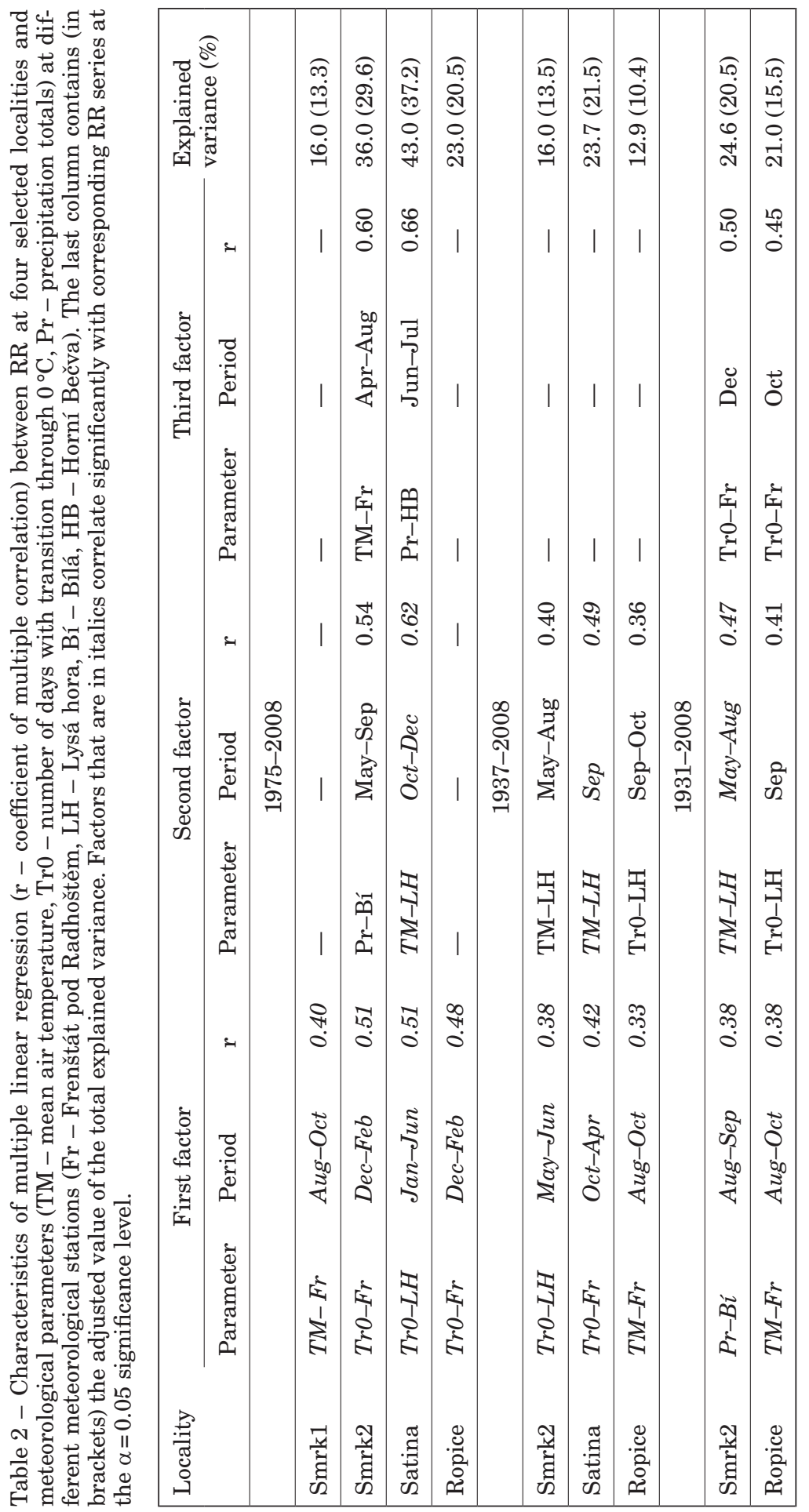


earthquake, estimated at $\mathrm{M}_{\mathrm{s}} \sim 6.6$, occurred on 27 February 1786 in the area of Český Těšín ca. 15 km from the Ropice site - see Brázdil, Kirchner, eds. 2007), we assume that climatic conditions constitute the major factor influencing rockfall processes. Correlations between individual RR time series, however, decrease with increasing lengths of reconstructed records. Particular localities are situated at various altitudes and their slopes are differently oriented. Temporal changes of climatic conditions within the studied area were thus of potentially different weights at the sites with distinctive morphometric characteristics. The weakening of correlation between RR at individual sites in the context of increasing $R R$ records could be attributed to this effect. A very similar situation (i.e. weakening of correlation with increasing lengths of time-series) appears if we turn our attention to the relationships between time-series of $R R$ and individual meteorological characteristics. Each extension of the reconstructed RR time series thus leads to a weakening of their correlation with meteorological characteristics. This probably arises out of several factors, for example, the changing role of individual meteorological parameters through time, the non-linearity of relationships between RR and meteorological triggers, and also the fact that the processes that trigger rockfall work on short time-scales and are not amenable to full description with the parameters used in this study.

One indicator of rockfall intensity approximated by RR index was obtained using dendrogeomorphic techniques, which provide reliable data, but we must remain aware of some of the limitations of this approach. Rockfall is, in comparison with landslides and debris flows, quite a discontinuous geomorphic process (individual rock clasts release individually from the rock face) and trees growing in its transport and accumulation zones do not encounter all the rock fragments in motion. Some of the moving clasts miss all the standing trees, or stop just below the cliff without reaching the forest boundary. On the other hand, some of the clasts released might hit several trees at a time in the course of their movement. Subsequently, it is not possible to determine which scars are due to the motion of one individual rock fragment (i.e. one rockfall event). Furthermore, the sum of the widths of individual trees growing under the rock face is only a fraction of the width of the entire cliff. Thus, it is very probable that the majority of rock clasts released during rockfall events impact none of the trees present. And last but not least, identification of rockfallrelated growth disturbances from increment cores is limited, because of the impossibility of dating of all the scars overgrown within the tree trunks (Stoffel, Perret 2006). Intensity of rockfall demonstrated by RR index is therefore only an approximation of the "real intensity" and RR should be considered as minimal values.

Some uncertainty is also associated with the meteorological data. It would be ideal to have detailed meteorological measurements taken exactly at the study sites, thus enabling characterization of the microclimatic patterns that cannot by followed by the spatial distribution of the standard CHMI network of meteorological stations. Another negative derives from the nature of the temperature data, for which only the basin station at Frenštát pod Radhoštěm and a top station at Lysá hora were available, although all the RR sites are located at altitudes between $600 \mathrm{~m}$ and $970 \mathrm{~m}$. This means that the meteorological stations used show a more general tendency, at a far larger spatial scale than local peculiarities. 
The RR datasets obtained depict the influence of selected meteorological characteristics on the intensity of rockfall processes in the Flysch Carpathians. Transitions through $0^{\circ} \mathrm{C}$ (i.e. freeze-thaw cycles) emerge as the major factor, characterized by the highest correlations with RR values. Swift temperature changes, potentially associated with water melting and freezing within rock fractures, represent the main driving factor for rockfall in the Moravskoslezské Beskydy Mountains. Similar results have been published from the Swiss Alps (Matsuoka 2008). Less important, but statistically significant (mainly in the spring months), is the influence of monthly, seasonal and annual mean temperatures. It is evident that low temperatures are associated with higher RR values in the area studied. Relationships between air temperature and intensity of rockfall have been described by Luckman (1976) and Ishikawa, Kurashige, Hirakawa (2004). Perret, Stoffel, Kienholz (2006) also assigned a significant role to air temperature, but in the opposite sense, i.e. that higher average summer and winter temperatures positively influence the intensity of rockfall. These results were, however, obtained from different geographical settings (the Swiss Alps) and with the use of smoothed time-series of meteorological characteristics. Mean monthly, seasonal and annual precipitation totals appear to be less important in driving rockfall intensity within the sites studied. Similar results have been discussed by Perret, Stoffel, Kienholz (2006). However, Schneuwly, Stoffel (2008b) report the possibility that rockfall is accelerated during heavy summer storms. In spite of the fact that our study did not verify such processes within the studied area, earlier observations in the Czech Flysch Carpathians provided evidence of rainfall-related rockfalls during extreme rainfalls in July 1997 (Kirchner, Krejčí 1998). The hierarchy of dominant factors driving rockfall intensity (days with transition through $0^{\circ} \mathrm{C}$ - air temperatures - precipitation) within the sites studied was also verified by applied multiple stepwise linear regression.

\section{Conclusions}

The analysis of chronological relationships between meteorological characteristics and rockfall intensity is new for the territory of the Czech Flysch Carpathians. The same is true of the reconstruction of rockfall dynamics through dendrogeomorpic techniques, never before employed in this part of Europe. We analyzed reconstructed time-series of rockfall rate from four localities within the territory of the Moravskoslezské Beskydy Mountains. Despite the fact that the lengths of individual RR time series are limited by the ages of tree populations at each site, the longest records reached back as far as 78 years (AD 1931-2008).

There is no doubt that rockfall is a complex process dependent on many natural factors, including the meteorological. This complexity renders difficult the disclosure of clear relations between $\mathrm{RR}$ series and meteorological elements. Moreover, great bias in the development of RR series, as well as uncertainties in microclimatic patterns at individual sites, complicate the performance of analysis. Moreover, the role of individual meteorological variables on $R R$ changes through time and space. For certain periods of time and certain sites this role may even be statistically significant. Several statistically significant relations 
of RR to TM, Tr0 and Pr demonstrate that the relation studied actually exists and may even be quantified in some way. Quantification of these relations may be taken as the most important contribution of this paper to the study of the influence of meteorological factors on rockfall.

Acknowledgements: We would like to extend our thanks to Ondřej Turský and Marek Václavek (Ostrava University, Ostrava) for their valuable help in the preparation of rockfall chronologies, and to Mr. Tony Long (Svinošice) for English style corrections.

\section{References:}

ALEXANDERSSON, A. (1986): A homogeneity test applied to precipitation data. Journal of Climatology, 6, No. 6, pp. 661-675.

ALEXANDERSSON, A. (1995): Homogeneity testing, multiple breaks and trends. In: Proceedings of the 6th International Meeting on Statistical Climatology, Galway, Ireland, 19-23 June, pp. 439-441.

BECKER, A., DAVENPORT, C. (2005): Rockfalls triggered by the AD 1356 Basle Earthquake. Terra Nova, 15 , No. 4, pp. 258-264.

BERGER, F., QUETEL, C., DORREN, L.K.A. (2002): Forest: A natural protection mean against rockfall, but with which efficiency? The objectives and methodology of the ROCKFOR project. Interpavement, 2, pp. 815-826.

BRÄKER, O.U. (2002): Measuring and data processing in tree-ring research - a methodological introduction. Dendrochronologia, 20, No. 1-2, pp. 203-216.

BRÁZDIL, R., KIRCHNER, K., eds. (2007): Vybrané př́írodní extrémy a jejich dopady na Moravě a ve Slezsku. Masarykova univerzita, Český hydrometeorologický ústav, Ústav geoniky Akademie věd České republiky, v. v.i., Brno, Praha, Ostrava, 432 pp.

BRÁZDIL, R., ŠTĚPÁNEK, P. (1998): Kolísání teploty vzduchu v Brně v období 1891-1995. Geografie, 103, No. 1, pp. 13-30.

COE, J.A., HARP, E.L. (2007): Influence of tectonic folding on rockfall susceptibility, American Fork Canyon, Utah, USA. Natural Hazards and Earth System Science, 7, No. 1, pp. 1-14.

DAVIES, M.C.R., HAMZA, O., HARRIS, C. (2001): The effect of rise in mean annual temperatures on the stability of rock slopes containing ice filled discontinuities. Permafrost and Periglacial Processes, 12, No. 1, pp. 137-144.

FALC, Z. (2001): Finanční pomoc státu při stabilizaci sesuvů v regionech postižených následky povodní. Materiály tiskového oddělení MŽP ČR, Praha.

GRUBER, S., HOELZLE, M., HAEBERLI, W. (2004): Permafrost thaw and destabilization of Alpine rock walls in the hot summer of 2003. Geophysical Research Letters, 31, No. 13, L13504.

GRUNER, O. (2008): Klimatische und meteorologische Einflüsse auf Sturzprozesse. Interpraevent, Conference Proceedings, Dorbin Vorarlberg, Austria, 26-30 May, Vol. 2, pp. 147-158.

HRADECKÝ, J., PÁNEK, T. (2008): Deep-seated gravitational slope deformations and their influence on consequent mass movements (case studies from the highest part of the Czech Carpathians). Natural Hazards, 45, No. 2, pp. 235-253.

ISHIKAWA, M., KURASHIGE, Y., HIRAKAWA, K. (2004): Analysis of crack movements observed in an alpine bedrock cliff. Earth Surface Processes and Landforms, 29, No. 7, pp. 883-891.

JABOYEDOFF, M., BAILLIFARD, F., BARDOU, E., GIROD, F. (2004): The effect of weathering on alpine rock instability. Quarterly Journal of Engineering Geology \& Hydrogeology, 37, No. 2, pp. 95-103.

KIRCHNER, K., KREJČ́, O. (1998): Slope movements in the Flysch Carpathians of Eastern Moravia (Vsetín District), triggered by extreme rainfalls in 1997. Moravian Geographical Reports, 6, No. 1, pp. 43-52. 
KIRCHNER, K., KREJČÍ, O., MÁČKA, Z., BÍL, M. (2000): Slope deformations in eastern Moravia, Vsetín District (Outer Western Carpathians). AUC Geographica, 35, Supplementum, pp. 133-143.

KLIMEŠ, J. (2011): Rockfall hazard and risk assessment on forested slopes, examples from Czechia. Geografie, 116, No. 2, pp. 144-155.

KREJČÍ, O., BAROÑ, I., BÍL, M., HUBATKA, F., JUROVÁ, Z., KIRCHNER, K. (2002): Slope movements in the Flysch Carpathians of Eastern Czech Republic triggered by extreme rainfalls in 1997: a case study. Physics and Chemistry of the Earth, 27, No. 36, pp. 1567-1576.

KUKAL, Z., POŠMOURNÝ, K. (2005): Př́rodní katastrofy a rizika. Planeta, 12, No. 3, pp. 1-52.

LUCKMAN, B.H. (1976): Rockfalls and rockfall inventory data: some observations from Surprise Valley, Jasper National Park, Canada. Earth Surface Processes, 1, No. 3, pp. 287-298.

MARZORATI, S., LUZI, L., DE AMICIS, M. (2002): Rock falls induced by earthquakes: a statistical approach. Soil Dynamics and Earthquake Engineering, 22, No. 7, pp. 565-577.

MATSUOKA, N. (2008): Frost weathering and rockwall erosion in the southeastern Swiss Alps: Long-term (1994-2006) observations. Geomorphology, 99, No. 1-4, pp. 353-368.

MATSUOKA, N., SAKAI, H. (1999): Rockfall activity from an alpine cliff during thawing periods. Geomorphology, 28, No. 3-4, pp. 309-328.

MENČÍK, E., ADAMOVA, M., DVOŘ́K, J., DUDEK, A., JETEL, J., JURKOVÁ, A., HANZLÍKOVÁ, E., HOUŠA, V., PESLOVÁ, H., RYBÁŘOVÁ, L., ŠMÍD, B., ŠEBESTA, J., TYRÁČEK, J., VAŠÍČEK, Z. (1983): Geologie Moravskoslezských Beskyd a Podbeskydské pahorkatiny. Ústřední ústav geologický, Praha, 304 pp.

PÁNEK, T., HRADECKÝ, J., MINÁR, J., HUNGR, O., DUŠEK, R. (2009): Late Holocene catastrophic slope collapse affected by deep-seated gravitational deformation in flysch: Ropice Mountain, Czech Republic. Geomorphology, 103, No. 3, pp. 414-429.

PERRET, S., STOFFEL, M., KIENHOLZ, H. (2006): Spatial and temporal rockfall activity in a forest stand in the Swiss Prealps - A dendrogeomorphological case study. Geomorphology, 74, No. 1-4, pp. 219-231.

RAPP, A. (1960): Recent developments in the mountain slopes in Kärkevagge and surroundings, northern Scandinavia. Geografiska Annaler, 42, No. 2/3, pp. 65-200.

RAVANEL, L., DELINE, P. (2011): Climate influence on rockfalls in high-Alpine steep rockwalls: The north side of the Aiguilles de Chamonix (Mont Blanc massif) since the end of the 'Little Ice Age'. The Holocene, 21, No. 2, pp. 357-365.

RYBÁŘ, J. (1999): Vliv klimatu na vývoj sesuvů a jiných nebezpečných svahových deformací. In: Geotechnické dny 1999. Sborník přednášek z odborného semináře Sesuvy a inženýrsko-geologické poměry Prahy věnované památce prof. Quido Záruby. Informační centrum České komory autorizovaných inženýrů a techniků činných ve výstavbě, Praha, pp. 36-45.

RYBÁŘ, J. (2007): Vliv klimatu na vývoj různých typů svahových pohybů. Zprávy o geologických výzkumech v roce 2006. Česká geologická služba, Praha, pp. 90-92.

SANDERSEN, F., BAKKEHØI, S., HESTENS, E., LIED, K. (1997): The influence of meteorological factors on the initiation of debris flows, rockfalls, rockslides and rockmass stability. Publikasjon - Norges Geotekniske Institutt, 201, pp. 97-114.

SCHNEUWLY, D.M., STOFFEL, M. (2008a): Spatial analysis of rockfall activity, bounce heights and geomorphic changes over the last 50 years - A case study using dendrogeomorphology. Geomorphology, 102, No. 3-4, pp. 522-531.

SCHNEUWLY, D.M., STOFFEL, M. (2008b): Tree-ring based reconstruction of the seasonal timing, major events and origin of rockfall on a case-study slope in the Swiss Alps. Natural Hazards and Earth System Science, 8, No. 2, pp. 203-211.

STEMBERK, J., ZVELEBIL, J. (1998): Skalní řícení v kvádrových pískovcích v první polovině roku 1998 na Děčínsku. Geotechnika, 1, No. 4, pp. 10-12.

STOFFEL, M., BOLLSCHWEILER, M., LIÈVRE, I., DELALOYE, R., MYINT, M., MONBARON, M. (2005): Analyzing rockfall activity (1600-2002) in a protection forest - a case study using dendrogeomorphology. Geomorphology, 68, No. 3-4, pp. 224-241.

STOFFEL, M., PERRET, S. (2006): Reconstructing past rockfall activity with tree rings: Some methodological considerations. Dendrochronologia, 24, No. 1, pp. 1-15. 
ŠILHÁN, K., BRÁZDIL, R., PÁNEK, T., DOBROVOLNÝ, P., KAŠIČKOVÁ, L., TOLASZ, R., TURSKÝ, O., VÁCLAVEK, M. (2011): Evaluation of meteorological controls of reconstructed rockfall activity in the Czech Flysch Carpathians. Earth Surface Processes and Landforms, 36, No. 14, pp. 1898-1909.

ŠTĚPÁNEK, P. (2004): Homogenizace teploty vzduchu na území České republiky v období přístrojových pozorování. Práce a studie, 32. Český hydrometeorologický ústav, Praha, $56 \mathrm{pp}$.

ŠTĚPÁNEK, P. (2007): AnClim - software for time series analysis. Institute of Geography, Faculty of Natural Sciences, MU, Brno, 1.47 MB. http://www.climahom.eu/AnClim.html.

TOLASZ, R., MÍKOVÁ, T., VALERIÁNOVÁ, A., VOŽENÍLEK, V., eds. (2007): Climate Atlas of Czechia. Ceský hydrometeorologický ústav, Palackého univerzita, Praha, Olomouc, 256 pp.

VAŘILOVÁ, Z., ZVELEBIL, J., PALUŠ, M. (2011): Complex system approach to interpretation of monitoring time series: two case histories from NW Bohemia. Landslides, 8, No. 2, pp. 207-220.

ZAVORAL, J. (2002): Sanace nestabilních objektů v Hřensku. Geotechnika, 5, No. 3, pp. 13-16.

ZVELEBIL, J. (1995): Determination of characteristic features of slope movements present day activity by monitoring in thick-bedded sandstones of the Bohemian Cretaceous Basin. AUC Geographica, 30, Supplementum, pp. 79-113.

ZVELEBIL, J., MOSER, M. (2001): Monitoring based time-prediction of rock falls: Three casehistories. Physics and Chemistry of the Earth, Part B: Hydrology, Oceans and Atmosphere, 26, No. 2, pp. 159-167.

\section{Shrnutí}

\section{VLIV METEOROLOGICKÝCH FAKTORŮ NA SKALNÍ ŘÍCENÍ V MORAVSKOSLEZSKÝCH BESKYDECH}

Metody dendrogeomorfologického výzkumu byly využity ke studiu frekvence skalního řícení v Moravskoslezských Beskydech. Pro čtyři lokality (Smrk1 - 600-650 m n. m., Smrk2 810-870 m n. m., Ropice - 910-970 m n. m., Satina - 800-870 m n. m. - obr. 1-2, tab. 1) byly sestaveny řady intenzity skalního řícení (dále $R R$ ) počítané ze vztahu:

$R R=\sum R E y \div E D y$,

kde $R E$ jsou případy skalního řícení v roce $y$ a $E D$ je suma průměrů všech stromů v roce $y$. ED jednoho stromu v roce y je definováno jako roční míra přírůstku stromu násobená věkem stromu v rocích. Všechny lokality pokrývají hodnotami RR období 1975-2008, bez Smrku1 období 1937-2008 a pouze Smrk2 a Ropice mají souvislé řady v letech 1931-2008 (obr. 3). V období 1975-2008 byla statisticky významná korelace hodnot RR lokality Ropice s třemi zbylými lokalitami a Smrku2 se Satinou, zatímco pro dvě nejbližší místa Smrk1 a Smrk2 byla statisticky nevýznamná.

Jako meteorologické faktory byly vybrány průměrné teploty vzduchu (TM), počty dnů s přechodem teploty přes $0^{\circ} \mathrm{C}$ (Tr0) a množství srážek (Pr). V̌̌echny tyto klimatologické charakteristiky byly $\mathrm{k}$ dispozici pro stanice Frenštát pod Radhoštěm a Lysá hora, přičemž úhrny srážek byly použity také na šesti dalších stanicích. Protože řady RR postrádají bližší roční specifikaci výskytu skalního řícení, byly hodnoty RR korelovány s měsíčními, sezonními a ročními řadami uvedených klimatologických charakteristik. Hodnoty RR a TM vykazují převážně záporné korelační koeficienty (obr. 4), tj. nižším průměrným teplotám vzduchu odpovídají vyšší hodnoty RR. Naopak v případě Tr0 jsou jejich korelační koeficienty s RR převážně kladné (obr. 5), tedy vyšší počet dnů s přechodem teplot vzduchu přes $0^{\circ} \mathrm{C}$ je příznivý pro vyšší frekvenci skalního řícení. Za spíše nahodilé lze považovat převážně statisticky nevýznamné korelační koeficienty RR se srážkovými úhrny Pr (obr. 6).

$\mathrm{K}$ postižení významu jednotlivých meteorologických faktorů na skalní řícení byla použita metoda vícenásobné lineární regrese (obr. 7, tab. 2). Její aplikace ukázala, že pomocí studovaných faktorů lze vysvětlit mezi $13 \%$ (Ropice) a $43 \%$ (Satina) celkové variability odpovídajících RR řad. Jako nejvýznamnější použitý faktor se jeví Tr0 (v pěti případech) následované TM (ve třech případech) a v menší míre i Pr (v jednom případě). To ukazuje na rozhodující význam teplotních charakteristik, související nepochybně s regelačními cykly. 
Dendrogeomorfologické určení intenzity skalního řícení je zatíženo řadou nejistot (padající úlomky nemusí zasáhnout žádný strom; není možné identifikovat a datovat všechny zarostlé jizvy na kmenech) souvisejících se získáním RR řad, které je nutné považovat za dolní odhad skutečného počtu. Nejistoty v meteorologických datech souvisejí s použitím standardní sítě meteorologických stanic, která neumožňuje postihnout mikroklimatické podmínky jednotlivých lokalit, které mohou být odlišné od mezoklimatu dané oblasti. I přes uvedené nejistoty však bylo možné prokázat, že existuje statisticky významná kvantifikovatelná vazba mezi intenzitou skalního řícení a kolísáním studovaných klimatologických charakteristik, což lze považovat za hlavní přínos této studie.

Obr. 1 -Studovaná oblast s lokalitami skalního řícení a použitými meteorologickými stanicemi.

Obr. 2 - Topografické profily studovaných lokalit skalního řícení: A - Smrk1, B - Smrk2, C - Ropice, D - Satina.

Obr. 3 -Kolísání ročních řad RR na čtyřech studovaných lokalitách v období 1931-2008. Shlazeno pětiletým Gaussovým filtrem.

Obr. 4 - Pearsonovy korelační koeficienty mezi RR a měsíčními, sezonními a ročními průměrnými teplotami vzduchu: 1 - Frenštát pod Radhoštěm, 2 - Lysá hora. Horizontální čáry - kritické hodnoty korelačního koeficientu pro hladinu významnosti $\alpha=0,05$ podle jednostranného t-testu.

Obr. 5 -Pearsonovy korelační koeficienty mezi RR a měsíčními, sezonními a ročními počty dnů $\mathrm{s}$ přechodem přes $0^{\circ} \mathrm{C}: 1$ - Frenštát pod Radhoštěm, 2 - Lysá hora, 3 - žádné dny s přechodem přes $0^{\circ} \mathrm{C} v$ odpovídajících měsících/sezonách. Horizontální čáry kritické hodnoty korelačního koeficientu pro hladinu významnosti $\alpha=0,05$ podle jednostranného t-testu.

Obr. 6 -Pearsonovy korelační koeficienty mezi RR a měsíčními, sezonními a ročními úhrny srážek: 1 - Lysá hora, 2 - Bílá, 3 - Horní Bečva, 4 - Čeladná; Ropice 1975-2008: 1 - Lysá hora, 2 - Horní Lomná, 3 - Raškovice, 4 - Tyra. Horizontální čáry - kritické hodnoty korelačního koeficientu pro hladinu významnosti $\alpha=0,05$ podle jednostranného t-testu.

Obr. 7 - Histogramy hodnot prediktoru (RR) a prediktandi̊ (TM-LH, Tr0-LH, Pr-HB) a korelační graf mezi nimi s vhodnou jednoduchou lineární regresí pro Satinu, 1975-2008. Č́sla indikují objasněný rozptyl RR řad jednotlivými prediktandy (v \%).

Authors' affiliations: R. Brázdil, P. Dobrovolný and L. Kašičková are affiliated with Masaryk University, Faculty of Science, Institute of Geography, Kotlářská 2, 61137 Brno, Czechia; e-mail: brazdil@sci.muni.cz,dobro@sci.muni.cz, 123999@mail.muni.cz. K. Šilhán and T. Pánek are affiliated with University of Ostrava, Faculty of Science, Department of Physical Geography and Geoecology, Chitussiho 10, 71000 Ostrava, Czechia; e-mail: Karel. Silhan@osu.cz,Tomas.Panek@osu.cz.R.Tolasz is affiliated with Czech Hydrometeorological Institute, Na S̆abatce 17, 14306 Praha 4, Komořany, Czechia; e-mail: tolasz@chmi.cz.

Initial submission, 13 June 2011; final acceptance 5 January 2012.

\section{Please cite this article as:}

BRÁZDIL, R., ŠILHÁN, K., PÁNEK, T., DOBROVOLNÝ, P., KAŠIČKOVÁ, L., TOLASZ, R. (2012): The influence of meteorological factors on rockfall in the Moravskoslezské Beskydy Mts. Geografie, 117, No. 1, pp. 1-20. 